\title{
4Ps: A Strategy to Secure Customers' Loyalty via Customer Satisfaction
}

\author{
Mohammed T. Nuseir ${ }^{1} \&$ Hilda Madanat ${ }^{1}$ \\ ${ }^{1}$ Department of Management, Faculty of Business and Finances, The World Islamic Science \& Education \\ University, Jordan \\ Correspondence: Dr. Mohammed T. Nuseir, Department of Management, Faculty of Business and Finances, The \\ World Islamic Science \& Education University, Amman, Jordan. E-mail: drmnuseir@yahoo.com
}

$\begin{array}{lc}\text { Received: April 15, } 2015 & \text { Accepted: May 30, } 2015 \quad \text { Online Published: July 30, } 2015 \\ \text { doi:10.5539/ijms.v7n4p78 } & \text { URL: http://dx.doi.org/10.5539/ijms.v7n4p78 }\end{array}$

\begin{abstract}
This paper explores the role of Marketing mix strategy and its overall positive or negative impact on customer's satisfaction and loyalty. Product, price, place and promotion variables need to be managed by understating psychological traits of customers buying nature. The literary discussion highlights that customer expectations with regards to product quality, price, and product accessibility are managed by communication techniques using advertising agents. The discussion proceeds in analytical style using previous theory as base point to evaluate the role of marketing mix in relation with customer satisfaction turning into loyalty. Inductive data collection approach has proved a great help to extract gist of past research results. A large proportion of data has been gathered from secondary resources including journals, books and old research papers. The results show that all four aspects of marketing mix are equally important and any imbalance among them can damage overall results. Customers' buying intentions are greatly affected by his/her expectations in context of a product quality, price, and product accessibility. The relationship between customer satisfaction and loyalty depends on the elimination of perception gap, service gap, operational gap and behavioural gap that needs to be managed by giving focused attention to these matters. This paper reviews prior literature and proposes to think carefully to use marketing mix strategy to met customer expectations by eliminating any communication or perception gaps that further extend customer loyalty.
\end{abstract}

Keywords: marketing-mix, price, product, place, promotion, attitudinal, satisfaction, loyalty, variables, pricing

\section{Introduction}

Organisations devise marketing strategy to communicate with customers with the help of their attractive products and services structure. The strength of relationship between an organisation and a customer emerges in the form of customer's loyalty with organisational products. To attract customers and to sell a product profitably; organisations relay on innovation and enhanced quality standards of their services that are exhibited through marketing strategy. Marketing strategy is an emblem of diverse, unique and attractive marketing initiatives that are devised to prompt financial growth and to capacitate the sustainability of organisational growth. Marketing strategy is a visual aspect of marketing planning that indicates strategic dynamics of an organisation based on organisational business vision. Marketing planning, marketing mix, and marketing modelling initiatives are adopted to maximise and to secure optimal competitive advantages by satisfying customers' needs. Marketing strategy reveals organisation's hunger to dominate in the market by using different marketing perceptual notions to increase its customers' satisfaction. An organisation uses Cause Related Marketing (CRM) initiatives to present itself a socially responsible company in corporate environment to attract new customers (Agarwal et al., 2010).

High market share of an organisation unfolds the strength of a successful marketing strategy (Bee, 2009). Strong customer oriented strategies inspire customers to stay loyal and organisations use their loyalty to attract new customers (Ferguson \& Brohaugh, 2008). One of the dynamic tools is the timely and right introduction of Marketing Mix strategy that corresponds with the notion of 4Ps; product, policy, pricing, and promotion. Marketing mix strategy is used to analyse the psychological condition of buyers to attract customers to relay on company products by evaluating customers' buying capacity and attracting customers' by adopting certain measures of communication. Price and quality are phenomenal aspects of any product that are related to 
customer needs (Robins, 1994). Customers' satisfaction generates positive and productive impact on business growth. Having significant number of customers means that the organisation has strong competitive position over other businesses rivals. Satisfaction is a major cause behind revenue growth as satisfied customers return for another purchase. Loyalty, according to Sasser (1990), benefits an organisation in four different ways such as: (1) loyal customers re-buy the product of the same company despite having an alternative option, (2) spend good amount of money, (3) source of recommendation to other new customers and (4) give useful and sincere feedback to improve the services structure or product quality.

\section{Literature Review}

\subsection{The Need of Making a Strategy}

Organisations devise marketing strategy to accomplish unfinished desires of customers. The goal of marketing strategy thus emerges in two ways action such as providing good value to customers against their spending and building strong bond with customers by satisfying customers' needs resulting in profitability. Devising strong and result oriented marketing strategy requires valuable and precise analysis of the market and diagnostic evaluation of the factors associated with the market such as competitors' business approaches, customers' needs and organisational capacity in the form of available resources to compete in the market (Winer, 2004). Marketing mix strategy is "the mix of controllable marketing variables that the firm uses to pursue the desired level of sales in the target market" (Churchill \& Peter, 1995, p. 6). There is a great swing in marketing strategy in present times as now marketing strategies are customer focused. The primary concept of using marketing mix, hence, is to be superior in performance by knowing and complying with customer's needs and requirements (Armstrong \& Kotler, 2011). Customer driven strategy is also known as market driven strategy that helps to evaluate and highlight the market trends based on customers' needs and demands (Wheelen \& Hunger, 2008).

\subsection{Marketing Mix: The Notion of $4 P$ s}

Marketing-Mix strategy known as 4Ps is related to product, price, place and promotion. Organisations focus on two types of strategic processes to devise marketing mix. The first process is to select the market where organisation wants to penetrate and the second is the development procedure of 4Ps combining all aspects of marketing mix such as price, place, product and promotion to satisfy customers (Kanagal, 2009).

\subsubsection{Product}

Goods or services that are launched in the market to be consumed or to be used by customers to satisfy their needs and demands are called products (Armstrong \& Kotler, 2006). However, there is another opinion about the definition of product as shared by Hirankitti, Mechinda and Manjing (2009) that the concept of service as product is based on two aspects. The first is prolific service that demonstrates core benefits and the second is secondary level services that are tangible and augmented. The latter is related to delivery of key services. Product is primary aspect of marketing mix and every product as argued by Ferrell (2005), differentiates itself from another product on the basis of its characteristics. Its characteristics as mentioned by Borden (1984) include quality that is major concern of every customer, design: that attracts customers, features: that enable customers to buy new product and brand name that increases loyalty.

\subsubsection{Price}

Price is the value that is charged against the service or product provided to a customer. Price impacts significantly on customer's psychology and helps to decide to repurchase a product (Kotler et al., 2008). The decision of pricing a product depends on many factors that include buying power of customer, cost of product and cost of product delivery (Parasuraman \& Grewal, 2000). Price is a major factor behind satisfaction \& product loyalty because a customer carefully perceives if he is getting the most benefit from the product against his spending (Peter \& Donnely, 2007).

\subsubsection{Place}

The concept of place is related to the availability of a product to a customer (Armstrong \& Kotler, 2006). However, the concept of place is not merely limited to Armstrong's and Kotler's definition as Hirankitti et al. (2009) notes that the concept of place includes distribution channels and location as well. The distribution facilities and location are major factors to meet demand and supply of a product and to overcome variables that hinder supply of a product to a targeted market (Copley, 2004).

\subsubsection{Promotion}

Promotion is advertisement of a product to sell it to a customer and this process is also acknowledged as communication with customers using various means of advertising. The core aspect of promotion is to reduce the 
communication gap that occurs between an organisation and the customer (Lovelock \& Wright, 2002). Strategic initiatives focus on exploiting media advertising opportunities to communicate with customers to attract and persuade customers to buy company product (Munusamy \& Hoo, 2008).

\section{$2.34 P$ s and Customer Satisfaction and Loyalty}

Marketing mix is a major contributor to boost customer loyalty with regard to company products. Oliver (1997, p. 14) perceives satisfaction turning into loyalty as a process of commitment that further can be understood as "a deeply held commitment to re-buy or re-patronize a preferred product or service consistently in the future, despite situational influences and marketing efforts having the potential to cause switching behaviour." Customer commitment shows four aspects as behind the curtain causes to increase business profitability and that includes (1) belief, that organisation will produce the return of the spent money and it actually happens, (2) favoured attitude, that appears as repurchasing of products, (3) behavioural intention, that shows that satisfied and loyal customers will certainly buy the product again and (4) loyal customers suggest to take action to overcome organisational deficiencies to prove itself better from other market competitors (Oliver, 1997). Marketing mix is predominant aspect of marketing strategy that increases customers' satisfaction; hence, organisations face this challenge seriously that results to achieve greater market share. Higher number of satisfied customers according to Rust et al. (2000) enable organisations to serve in a better way by improving services structure or product quality further. Similarly, it is believed as investigated by Reichheld and Sasser (1990) that it is comparatively easy for an organisation to satisfy high level loyalty customers because their trust towards company products and services is greater and such customers are ready to pay more. High level of loyalty thus emerges as cost effective element for an organisation and major source to boost profitability. The evaluation of customers' satisfaction is determined by pre purchase and post purchase experiences if the product meets desired demands of a customer or exceeds to customers' expectations (Anderson and Swaminathan, 2011). Market oriented initiatives help to mitigate various week marketing variables that can distract customers' loyalty and the elimination of these variables mounts customers' satisfaction and loyalty (Luo, Homburg and Wieseke, 2010). The relationship between customer satisfaction and loyalty is hard to deny. However, the strength of this relationship depends on the organisational strength of strong competitive position of the organisation. Last few decades witness that brand loyalty has appeared as a major element in marketing studies. Brand loyalty reduces the cost of product in comparison to efforts that are made to attract new customers. Brand loyalty appears as a major factor in services sector. Customers' loyalty to company brand improves organisation's reputation (Bontis et al., 2007). Organisations involve loyal customers in a process that is known as 'Experiential marketing'. Customers participate to evaluate the standards of the brand and provide suggestions to enhance further quality. This process is also known as 'Engagement marketing' because the connection between a customer and brand highlights positive and negative characteristics of a product focused by loyal customers. Supply chain appears to contribute to exceed customers' loyalty towards organisation and its brands. The timely dispatch of products and its right time reach to customers involve various aspects of planning and manufacturing that are prioritized to maximise customer satisfaction and loyalty. Suppliers, manufacturers, distributors and end customers are part of supply chain that ultimately increase organisation's capacity to perform better to satisfy a customer (Poirier, 1990). Timely delivery of products to customers is critical issue that is focused a lot. Strong channels of distribution make sure that customers get their desired product in time and this ultimately increases customers' trust because they satisfy their needs as they desire for (Cravens \& Piercy, 2007). Pricing a product is another factor that attracts existing as well as new customers. Collins and Parsa (2006) highlight three techniques used in pricing a product and these techniques increase customers' satisfaction. (1) Cost based pricing involves all aspect of costs related to product production, distribution and the level of profitability. (2) Customer driven pricing corresponds with principles of spending capacity that a customer has. (3) Market driven approach that determines the price of similar product in the market produced by competitors and associated factors such as market share of the organisation. However, the crucial factor to determine the price of a product as determined by Cravens and Piercy (2007) is based on customers' response against the value of a product that is figured out by conducting market analysis. Promotion techniques as investigated by Hollensen (2007) reduce the gap of communication between a customer \& the organisation because a customer is attracted toward a particular product by using promotional standards that include advertisement of company products using technology, multimedia, newspapers and other promotion tricks. Promotion techniques according to Mills' (2003) logic also influence the pricing aspect of a product as customers' attraction convinces customers to spend money. In a detailed research, Jensen and Jepsen (2006) find that integration of online and offline promotion techniques are sources of direct and indirect marketing and produce chances for customers to choose his/her desired product directly. The focus of 4Ps is to increase profitability by canvassing colourful picture of a product and its quality characteristics to convince a customer to buy the product. Jerenz (2008) notes that 'Yield Management', is 
productive management approach to increase customer satisfaction and latter turning it into loyalty. The primary concept of yield management is to varying the price of a product and inventory control. Yield management is a part of 4Ps because its mechanism is related to pricing techniques as consideration is paid to customers' affordability and capacity of buying a product. Customer and the market are the focus of marketing mix and these two factors either bring success or failure for an organisation. Right and timely perception of customers' needs and idealizing the perceptual impact of marketing trends enable the organisation to produce the exact value to a customer that he/she desires for. The effective integration of marketing mix notions will make the organisation superior and at the same time helps to fasten the relationship between the customer and the organisation based on mutual respect backed by customer satisfaction, loyalty and organisation initiatives of quality standards (Cravens \& Piercy, 2007: Li \& Green, 2010).

\section{Research Model and Hypotheses}

Marketing mix or 4Ps has been constant source of inspiration for market researchers to explore its impact on customer satisfaction and loyalty. Previous research brings out some interesting facts about 4Ps that help organisations to bring improvements in services structure and product quality. This study of marketing mix is an extension of the series of research investigations conducted in the past by various authors but is unique in prospect as it raises questions if customer satisfaction and loyalty should be investigated in relation with 4Ps concept only. This research focuses on three general aspects of marketing strategy such as Marketing Mix (product, price, place and promotion), Customer Perceived Value (Perceived quality and sacrifice) and Customer loyalty (Word-of-mouth, price incentive, and repurchase intention and complaint behaviour). The hypothesis section leads the debate to explore marketing mix with deep analysis with the support of theory. The hypothesis discussion is based on conceptual model of marketing mix given as under.

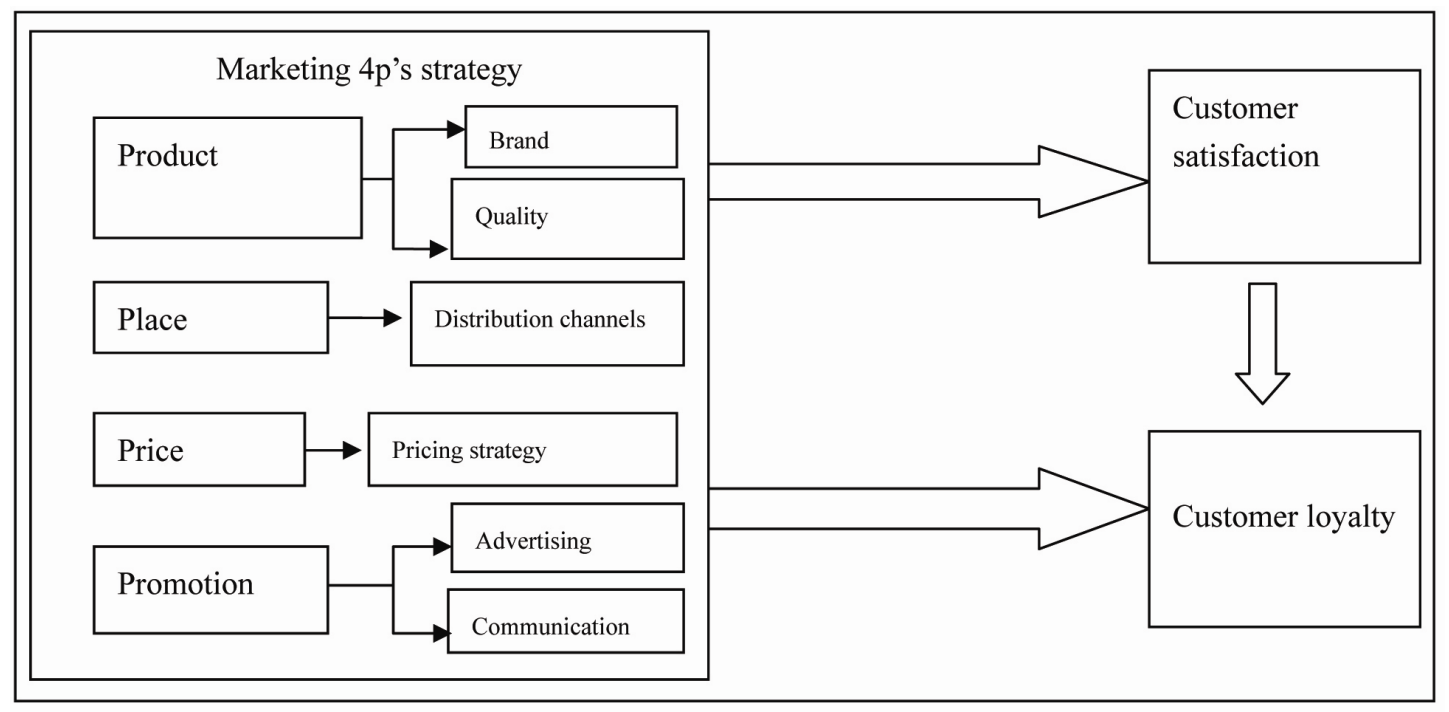

\subsection{Model Variables}

Model variables are of two types; one type directly influences customer satisfaction and the second is concerned with customer loyalty. Product and place related variables include brand, quality and distribution channels and their capacity to increase or decrease the satisfaction levels of a customer. Similarly, the second types of variables include pricing strategy, advertising and communication that boost customer loyalty. Any of these variables has the capacity to disturb the whole concept of marketing mix that results in sheer decline in business success. The careful consideration and managing each and every variable is must to win customer loyalty.

\subsection{Proposed hypotheses}

To test the study model, the following hypotheses has been proposed: 


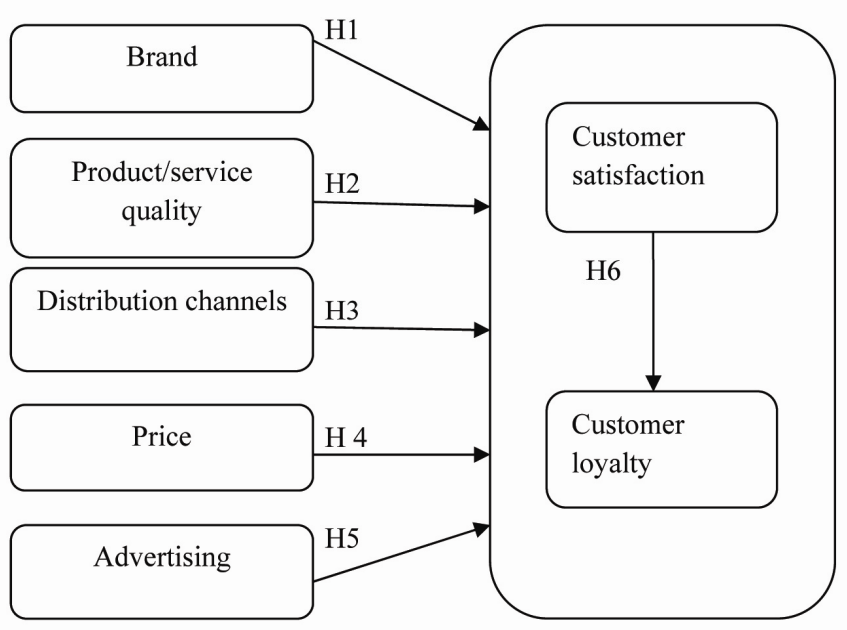

H1: Strong brand has a significant effect on customer satisfaction and loyalty.

Customer satisfaction and support are preliminary aspects behind attitudinal brand loyalty. Satisfaction emerges in response to customer's perceived value of the product or service he buys or hires. The stronger level of satisfaction increases loyalty on company products but this loyalty sometimes poses serious threats if customer response is negative due to a certain bad experience. A single bad experience alters the attitudinal mood of loyal customer that further inclines the customer to experience the available alternate product. The distrust of loyal customer alarms the prospective new customers to carefully decide to use the product or service of concerned organisation (Bennett et al., 2005). The significance of a brand for an organisation is not merely concise to a product but brand reputation acquires more market place that generates more market benefits. Brand popularity emerges as flag of success that produces inspirational atmosphere for customers and for the organisation (Bee, 2009). Organisations espouse this trend of branding to stay active in the eyes of customers. Keller (2009) presents strong reasons in favour of brand effectiveness in relation customer satisfaction turning into loyalty. The argument is that strong brand name increases the efficacy of marketing communication between the organisation and the customer. The concept of reliability is associated with brand name that ultimately proves cost effective because due to strong brand name organisations spend little for direct or indirect communication with customers. Brand fame imitates the role of communication by directly inspiring customers and convincing them for repurchase. Hence, the effect of brand name emerges significantly and positively in context of customer satisfaction and loyalty.

H2: Product quality has a significantly effect on customer satisfaction and loyalty.

A quality product casts strong impact on customer psychology and the acceptability of a product generates vast amount of satisfaction that inflames the sense of loyalty in a customer. The quality characteristics and price of each and every product varies; hence, its impact on consumer psychology appears differently (Spiteri \& Dion, 2004). The difference of perception changes the level of satisfaction and ultimately satisfaction changes the levels of loyalty (Auh \& Johnson, 2005). One of the primary concerns of a customer is related to the value of a product because the availability of alternate product attracts a customer. Even saving a trifle amount becomes the priority of a customer if the quality standards of other products are similar. High expectations bearing customers require higher quality and if an organisation is unable to perceive customers' requirements of quality standards then the loyalty of a customer is in jeopardy. Marketing mix, hence, determines the right value is delivered to the right customer for better end results (Ghazizadeh, Besheli, \& Talebi, 2010). The significance of services quality is similar to phenomenal aspects of product quality however services quality impact appears in two different ways. The first is reputation increase as customers compare services standards of an organisation with other market competitors and services satisfaction inclines customers to become a source of repute for the organisation. The second aspect appears as increase in profitability that is the results of customer loyalty (Lee et al., 2009). The intense competitive environment of business filed ultimately benefits the customer because a customer receives increased attention from the organisation that results in overall satisfaction (Khan, 2010). Investigations reveal that product quality generates satisfaction that latter changes into loyalty. However, this is not the issue with quality of services standards because the inspirational attitude of a customer helps him/her to decide to hire the service at an instant and this exhibits psychological aspect of loyalty (Lai et al., 2009; Auh \& Johnson, 2005). Quality or services standards that influence a customer positively and researched by Mincocha (2006) are known as superiority of product, inimitability, durability, non-substitutability and appropriability. 
H3: Distribution channels have a significant effect on customer satisfaction and loyalty.

Place is marketing mix phenomena that is directly linked to customer loyalty. The strength of distribution channels secures competitive position for the organisation. Logistics, timely production and dispatch of products in the market to make it accessible for customer increase customers' confidence on the organisation and such swift mechanism of product delivery indicates distribution capabilities of the organisation (Bee, 2009). Organisations adopt various channels for distribution that involves manufacturer, wholesaler, retailer and consumer (Strydom, 2005).

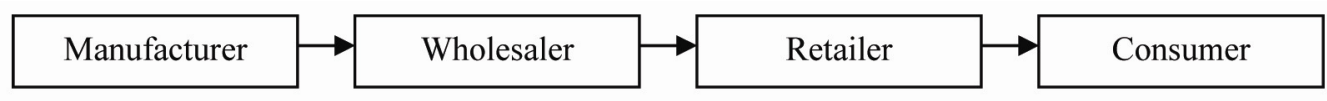

(Strydom, 2005, p. 124)

H4: Price has a significant effect on customer satisfaction and loyalty.

The economic factor shares pivotal role to establish a relationship between a customer and an organisation. Price has no direct link with customer loyalty but customer satisfaction that then turns into loyalty. Price is crucial for a customer as well as for the organisation because pricing a product influences both the parties. Organisations intend to secure their adequate profit but at the same time organisations do not intend to lose their customers because of higher price of a product (Auh \& Johnson, 2005). The notion of pricing involves the careful calculation of costs of business processes at internal and external levels and it is a major concern for decision makers. Poor pricing decisions snatch good market opportunities from organisations of attracting new customers and the result appears in sheer financial decline (Khouja \& Robbins, 2005). Price setting techniques vary at national and international levels because the business dimensions and customer choice differs from local markets. Some other factors significantly affect pricing strategy and this includes overall investment of the organisation, market influence, competitors' initiatives of pricing, and customer behaviour of spending money (Lancioni, 2005). Price and quality are related to each other and customers want the exact return of their spending and this return is the higher quality of a product or service. Satisfied customers are willing to spend more but do not compromise on quality standards (Goldschmidth \& Chung, 2001).

H5: Advertising has a significant effect on customer satisfaction and loyalty.

Organisations communicate with customers using advertising. It is a major source to get customers' attention and conveying organisation's message to target audience that are customers. Advertising is an element of success in domestic and global markets (Oyekunle, 2010). Advertising introduces customer to specific features of a product or service and highlights features of attraction that a customer looks for. Information on certain characteristics of products is made available for customer via advertising because organisations perceive that sharing such information would highlight their competitiveness with regard to their product (Chen \& Leu, 2011). Advertising changes customers' concepts about certain products and convince them to purchase the product that the advertisement is about. Advertising on media seamlessly convince customers to relay on certain brands because television commercials leave positive psychological impact on customers mind convincing them to make purchase. Digital media, internet services, television, radio, online forums and social media websites have broadened customers thinking because these advertising forums are unique and different from traditional methods of advertisement (Sharma, Herzog, \& Melfi, 2008). These advertisement tools or techniques establish strong communication between seller and buyer. Using media is strategic initiative rather a tactical decision because it directly influences the customer and convinces the customer to buy a product (Dewhirst \& Davis, 2005). Advertising, according to Hollensen (2007, p. 541) produces an organisation chances of global promotion of its products. This process of communication involves tree participants namely, sender, medium, receiver.

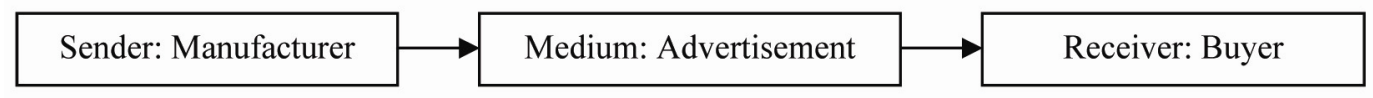

Organisations ponder carefully on the subject of using certain advertisement tools to communicate with customer. The preliminary aspect of advertisement-communication is to access that available communication opportunities that lead to analyse organisational capacity of available resources. This leads to set "marketing objective" and the preparation of communication task (Ronkainen \& Czinkota, 1998, p. 367). Effective communication via advertisement mounts customer's satisfaction on certain brands and this relationship latter develops in loyalty.

H6: Customer satisfaction has a significant effect on customer loyalty

Customer satisfaction turning into loyalty is highly discussed topic in marketing studies. One of the strong reasons of debate on customer satisfaction and loyalty (CS\&L) is its positive end results that emerge as increase 
in competitive position of the organisation in the market. The stronger position generates high volume of profitability that a business organisation aims at (Bayraktar et al., 2011). Researchers, according to Chang and Chang (2010) believe that it is vital for organisations to increase customer satisfaction because that leads to loyalty. Customer satisfaction is prerequisite to attain customers' loyalty. A highly satisfied customer stays loyal to company product for a longer period of time. Quality of a product, price, and accessibility of product are such notions that increase customer satisfaction. However, customer's psychological and behavioural natures count significantly in the process of loyalty. According to Gerpott et al. (2001) the quality without any doubt, influence a customer greatly and his/her satisfaction positively affects customer's purchase intention. The repurchasing occurs because a customer believes that he is going to get the right value of his investment. Alexander and Hill (2006, p. 6) note that dissatisfied customer leave an organisation at instant and research indicates that and organisation suffers from 10-30\% customer loss during a year. This happens because a gap between expectation and experience occurs. However, this gap exists at five levels such as (1) the promotional gap is related to organisational inability to provide standard services that are promised, (2) the understanding gap shows managers' inability to perceive customer requirements accurately, (3) the procedural gap shows organisational inability of poor translation of customers' expectations "into appropriate operating procedures", (4) the behavioural gap shows the difference between delivered service in relation to its specification and (5) the perception gap that shows customer's overwhelmed supposition about services standards and these suppositions are different from actual standards.

\section{Research Methodology}

The data to conduct this research has been gathered using inductive method approach. Previous studies and theories have been consulted at larger extent to support the idea that marketing mix generates positive impact on building good relationship between a customer and the organisation. The research relays on past investigation and further argument has been made using six hypotheses.

H1: Strong brand has a significant effect on customer satisfaction and loyalty.

H2: Product quality has a significantly effect on customer satisfaction and loyalty.

H3: Distribution channels have a significant effect on customer satisfaction and loyalty.

H4: Price has a significant effect on customer satisfaction and loyalty.

H5: Advertising has a significant effect on customer satisfaction and loyalty.

H6: Customer satisfaction has a significant effect on customer loyalty.

To investigate the significance of six hypotheses the study uses detailed research framework followed by international researchers. This framework as highlighted by Bell and Bryman (2006) involves extensive relay on previous theory and proved hypotheses. The findings of this research base on the past theory but the confirmation of hypothesis appears after deep analysis with the support of various theoretical perspectives of renowned researches. New hypotheses as used in this research and as confirmed by Haber and Wood (2006) support the research and end results clearly support the hypotheses. Qualitative method assisted in this research to know the underlying meaning of product, price, place and promotion and provided information about variables that disturb the marketing mix mechanism. The detailed information enabled to raise certain structured questions in the form of hypothesis that led to find detailed and multiple answers related to marketing mix. It is the use of research method that helped to know that psychological understanding of customer needs to be evaluated prior to know the attitudinal nature of buying a product.

\section{Research Findings}

Marketing mix effects are positive that emerge in the form of customer satisfaction and loyalty and bring good reputation for the organisation. 4Ps notion of product, price, place and promotion are equally significant to manage well. Marketing mix focuses on customers' intentions that boost customer satisfaction that latter turns into loyalty Quality of products and services lead an organisation to secure strong competitive position in the market and to attract new customers Pricing a product considering customers affordability increases organisation's reputation in the market and a good number of customers join the organisation to get maximum benefits from such approaches. Customer attraction is created by using advertising mediums or agents that highlight organisational capacity of communication with it customers directly. Using brand name not only secures existing customers but the inspirational impact attracts new customers The relationship between satisfaction and customer loyalty is not merely depend on the liking and disliking of a customer by a customer needs psychological satisfaction that convince him/her to make purchase. Organisations can increase business productivity by reducing any gap that exist as perception gap, services gap, operational gap and behavioural gap. 


\section{Conclusion}

Marketing mix assists organisations to perceive and understand the requirements and needs of customers. Product, price, place and promotion are such factors that lead any business towards success or failure. Understanding marketing needs based on customer perception of company product and its value secures strong competitive position for the organisation. Marketing mix variables directly damage customer perception of a product and this dissatisfaction alters attitudinal behaviour of the customer. Understanding customers' needs and careful attention to pricing products show that organisation's managers know to perceive psychological traits of customer's nature. Marketing mix if managed properly brings overall success for the organisation and at the same time is primary source to satisfy a customer.

\section{References}

Agarwal, P. K., Kumar, P., Swati, G., \& Tyagi, A. K. (2010). Cause Related Marketing in India: A Conceptual Paradigm. Advances in Management, 3(12).

Alexander, J., \& Hill, N. (2006). Handbook of Customer Satisfaction and Loyalty Measurement (3rd ed.). Gower Pub Co.

Anderson, R. E., \& Swaminathan, S. (2011). Customer Satisfaction and Loyalty in E-Markets: A PLS Path Modeling Approach. Journal of Marketing Theory and Practice, 19(2), 221-234 http://dx.doi.org/10.2753/MTP1069-6679190207

Armstrong, G., \& Kotler, P. H. (2011). Marketing an Introduction (10th ed.). New Jersey: Person Education.

Auh, S., \& Johnson, M. D. (2005). Compatibility effects in evaluations of satisfaction and loyalty. Journal of Economic Psychology, 26, 35-57. http://dx.doi.org/10.1016/j.joep.2003.10.002

Bayraktar, E., Tatoglu, E., Turkyilmaz, A., Delen, D., \& Zaim, S. (2011). Measuring the Efficiency of Customer Satisfaction and Loyalty for Mobile Phone Brands with DEA. Expert Systems with Applications http://dx.doi.org/10.1016/j.eswa.2011.06.041

Bee, A. H. (2009). Market share strategies in the pharmaceutical industry. Unitar e-Journal, 5(1), 129-169.

Bennett, R., Hartel, Ch. E. J., \& McColl-Kennedy, J. R. (2005). Experience as a moderator of involvement and satisfaction on brand loyalty in a business-to-business setting. Industrial Marketing Management, 34, 97-107. http://dx.doi.org/10.1016/j.indmarman.2004.08.003

Bodet, G. (2008). Customer satisfaction and loyalty in service: Two concepts, four constructs, several relationships. Journal of Retailing and Consumer Services, 15, 156-162 http://dx.doi.org/10.1016/j.jretconser.2007.11.004

Broadbent, J., \& Guthrie J. (2008). Public sector to public services: 20 years of "contextual" accounting research. Accounting, Auditing \& Accountability Journal, 21(2).

Chang, H. H., \& Chen, S. W. (2008). The impact of customer interface quality, satisfaction and switching costs on e-loyalty: Internet experience as a moderator. Computers in Human Behavior, 24, 2927-2944. http://dx.doi.org/10.1016/j.chb.2008.04.014

Chang, Y. W., \& Chang, Y. H. (2010). Does service recovery affect satisfaction and customer loyalty: An empirical study of airline services. Journal of Air Transport Management, 16, 340-342. http://dx.doi.org/10.1016/j.jairtraman.2010.05.001

Chen, F. P., \& Leu, J. D., (2011). Product involvement in the link between skepticism toward advertising and its effects. Social behavior and personality, 39(2), 153-160. http://dx.doi.org/10.2224/sbp.2011.39.2.153

Collins, M., \& Parsa, H. G. (2006). Pricing strategies to maximize revenues in the lodging industry. International Journal of Hospitality Management, 25, 91-107. http://dx.doi.org/10.1016/j.ijhm.2004.12.009

Cravens, D. W. \& Piercy, N. F. (2007). Strategic Marketing (9th ed.). MC Graw Hill.

Dewhirst, T., \& Davis, B. (2005). Brand strategy and integrated marketing communication (IMC). Jtiuniat of A/itvrliiwg, (4), 81-92. American Academy of Advertising.

Ferguson, R., \& Brohaugh, B. (2008). Telecom's search for the ultimate customer loyalty platform. Journal of Consumer Marketing, 25, 314-318. http://dx.doi.org/10.1108/07363760810890543

Ferguson, R., \& Hlavinka, K. (2006). Loyalty trends: three evolutionary trends to transform your loyalty strategy. Journal of Consumer Marketing, 23. 
Foreman, S. (2006). Power conflict and control in distribution channels. Henley Manager Update, 17(3).

Gerpott, T. J., Rams, W., \& Schindler, A. (2001). Customer retention, loyalty, and satisfaction in the German mobile cellular telecommunications market. Telecommunications Policy, 25, 249-269. http://dx.doi.org/10.1016/S0308-5961(00)00097-5

Ghazizadeh, M., Besheli, A. S., \& Talebi, V. (2010). Assessing of Bank Customers Retention and Loyalty: A Case Study of State-owned Banks in Tehran. European Journal of Social Sciences, 17(2).

Goldschmidt, N., \& Chung, B. (2001). Size does matter: the effect of organizational size and customer satisfaction. Journal of Quality Management, 6, 47-60. http://dx.doi.org/10.1016/S1084-8568(01)00028-1

Hollensen, S. (2007). Global Marketing (4th ed.). England UK, FT: Prentice Hall.

Jensen, M. B., \& Jepsen, A. L. (2006). Online Marketing Communications: Need for a New Typology for IMC? Journal of Website Promotion, 2(1/2). http://dx.doi.org/10.1080/15533610802104083

Keegan, J. W., \& Green, M. C. (2011). Global Marketing (6th ed.). New Jersey: Pearson Education.

Keller, K. (2006). Marketing Management (12th ed.). New Jersey: Prentice Hall.

Keller, K. L. (2009). Building strong brands in a modern marketing communications environment. Journal of Marketing Communications, 15, 139-155. http://dx.doi.org/10.1080/13527260902757530

Khan, M. A. (2010). An Empirical Assessment of Service Quality of Cellular Mobile Telephone Operators in Pakistan. Asian Social Science, 6(10). http://dx.doi.org/10.5539/ass.v6n10p164

Khouja, M., \& Robbins, S. S. (2005). Optimal pricing and quantity of products with two offerings. European Journal of Operational Research, 163, 530-544. http://dx.doi.org/10.1016/j.ejor.2003.10.036

Kotler, P. H., \& Bowen, J. T. (2010). Marketing for Hospitality and Tourism (5th ed.). New Jersey: Pearson Education.

Kotler, P., \& Keller, K. (2007). A framework for marketing management (3rd ed.). Pearson Prentice Hall.

Lai, F., Griffin, M., \& Babin, B. J. (2009). How quality, value, image, and satisfaction create loyalty at a Chinese telecom. Journal of Business Research, 62, 980-986. http://dx.doi.org/10.1016/j.jbusres.2008.10.015

Lancioni, R. (2005). Pricing issues in industrial marketing. Industrial Marketing Management, 34(2), 111-114. http://dx.doi.org/10.1016/j.indmarman.2004.07.009

Lee, M. S., Hsiao, H. D., \& Yang, M. F. (2009). The study of the relationships among experiential marketing, service quality, customer satisfaction and customer loyalty. The International Journal of Organizational Innovation.

Li, M. L., \& Green, R. D. (2010). A mediating influence on customer loyalty: The role of perceived value. Journal of Management and Marketing Research.

Luo, X., Homburg, C., \& Wieseke, J. (2010). Customer Satisfaction, Analyst Stock Recommendations, and Firm Value. Journal of Marketing Research, XLVII, 1041-1058. http://dx.doi.org/10.1509/jmkr.47.6.1041

Mincocha, S. (2006). What is strategy; Introduction. Strategic Challenges. Newcastle Business School. Published by Pearson Custom Publishing, UK.

Oyekunle, R. A. (2010). Patterns of Information Products Advertising in Newspaper Media in Nigeria. Afr.J. Lib, Arch. \& Inf. Sc., 20(2), 71-81.

Robins, F. (1994). The Teaching of Marketing Strategy. Marketing Education Review, 4, 10-15.

Ronkainen, A. I., \& Czinkota, R. M. (1998). International Marketing (5th ed.). USA: The Dryden Press.

Sharma, C., Herzog, J., \& Melfi, V. (2008). A five-points measurement framework for mobile advertising. International Journal of Mobile Marketing, 3(1).

Spiteri, J. M., \& Dion, P. A. (2004). Customer value, overall satisfaction, end-user loyalty, and market performance in detail intensive industries. Industrial Marketing Management, 33, 675-687. http://dx.doi.org/10.1016/j.indmarman.2004.03.005

Strydom, J. (2005). Introduction to Marketing (3rd ed.). Cape Town, South Africa: Juta Academics.

Wheelen, T. L., \& Hunger, J. D. (2008). Strategic management and business policy (11th ed.). New Jersey: Pearson International Edition, Prentice Hall.

Winer, R. S. (2004), Marketing Management (2nd ed.). Pearson Education International, Prentice Hall. 
Yang, Z., Wang X., \& Su, C. (2006). A review of research methodologies in international business. International Business Review, 15, 601-617. http://dx.doi.org/10.1016/j.ibusrev.2006.08.003

\section{Copyrights}

Copyright for this article is retained by the author(s), with first publication rights granted to the journal.

This is an open-access article distributed under the terms and conditions of the Creative Commons Attribution license (http://creativecommons.org/licenses/by/3.0/). 